\title{
Teaching NeuroImages: Lacunar stroke and polyarteritis nodosa
}

\section{Consider ADA2 deficiency (DADA2)}

Tayrine da Silva Gonçalves, MD, César Augusto Pinheiro Ferreira Alves, MD, José Albino da Paz, MD, and Leandro Tavares Lucato, MD, PhD

Neurology ${ }^{\circledR}$ 2019;92:e1801-e1802. doi:10.1212/WNL.0000000000007270

\section{Figure 1 Cutaneous feature}
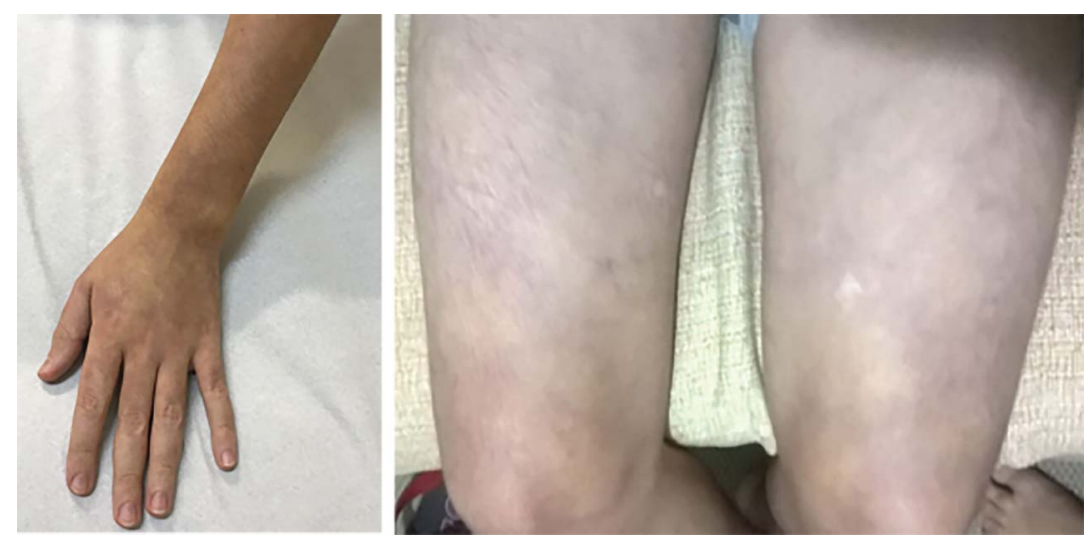

Livedo reticularis.

\author{
Correspondence \\ Dr. Gonçalves \\ tayrine.goncalves@ \\ hc.fm.usp.br
}

\section{MORE ONLINE}

$\rightarrow$ Teaching slides

links.lww.com/WNL/

A855

A 14-year-old boy with a 7-year history of livedo reticularis (figure 1) and initial diagnosis of cutaneous polyarteritis nodosa presented with acute impaired taste and tactile sensation on the tongue. One year prior, he showed left partial oculomotor palsy due to a lacunar midbrain stroke (figure 2A). New imaging (figure 2, B and C) revealed multifocal vertebrobasilar ischemia. Exome sequencing demonstrated compound heterozygosity in ADA2 (an intronic and a $G 47 \mathrm{R}^{1}$ mutation), confirming adenosine deaminase 2 deficiency, an early-onset autoinflammatory disease characterized by features of polyarteritis nodosa and stroke. ${ }^{2}$ The treatment was changed to adalimumab, whereas anti-tumor necrosis factor drugs are considered as first-line therapy. ${ }^{2,3}$

\section{Author contributions}

Tayrine da Silva Gonçalves: study concept and design, acquisition of data, analysis or interpretation of the data. César Augusto Pinheiro Ferreira Alves: study concept and design, analysis or interpretation of the data, critical revision of manuscript for intellectual content. José Albino da Paz: study supervision, analysis or interpretation of the data, critical revision of manuscript for intellectual content. Leandro Tavares Lucato: study supervision, analysis or interpretation of the data, critical revision of manuscript for intellectual content.

\section{Study funding}

No targeted funding reported. 

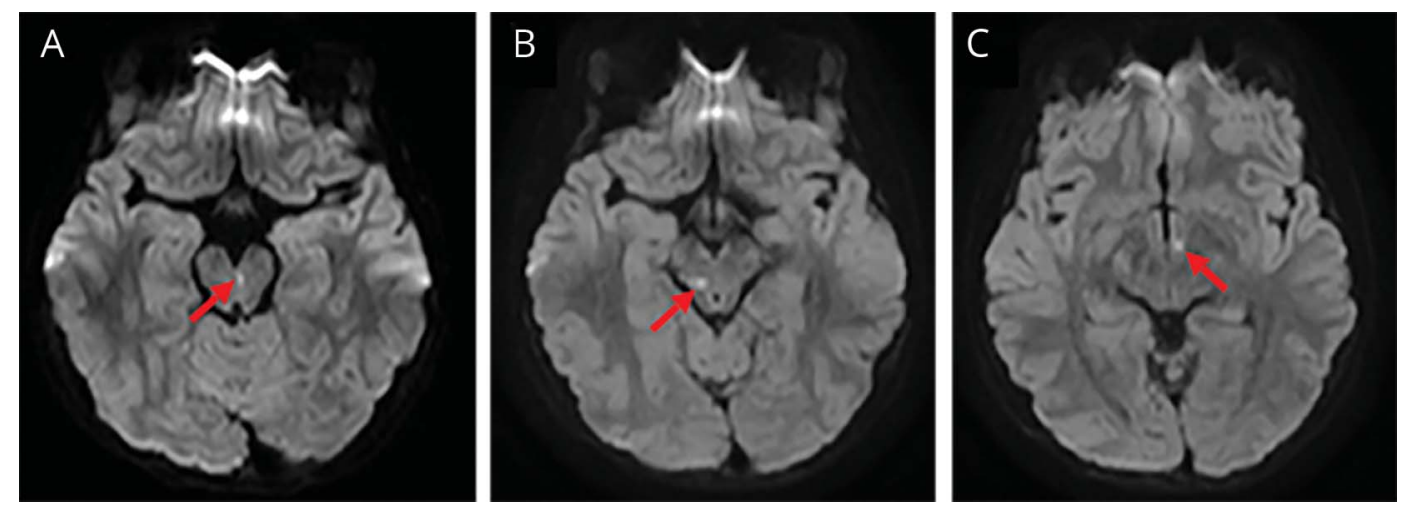

Very small acute ischemic foci, showing diffusion-weighted imaging hyperintensity. (A) First stroke involving left paramedian caudal midbrain. (B, C) Second stroke involving right midbrain lateral tegmentum (B) and hypothalamus left wall (C).

\section{Disclosure}

The authors report no disclosures relevant to the manuscript. Go to Neurology.org/N for full disclosures.

\section{References}

1. Caorsi R, Penco F, Schena F, Gattorno M. Monogenic polyarteritis: the lesson of ADA2 deficiency. Pediatr Rheumatol 2016;14:51.
2. Caorsi R, Penco F, Grossi A, et al. ADA2 deficiency (DADA2) as an unrecognised cause of early onset polyarteritis nodosa and stroke: a multicentre national study. Ann Rheum Dis 2017;76:1648-1656.

3. Meyts I, Aksentijevich I. Deficiency of adenosine deaminase 2 (DADA2): updates on the phenotype, genetics, pathogenesis, and treatment. J Clin Immunol 2018;38: 569-578. 


\section{Neurology}

\section{Teaching NeuroImages: Lacunar stroke and polyarteritis nodosa: Consider ADA2 deficiency (DADA2)}

Tayrine da Silva Gonçalves, César Augusto Pinheiro Ferreira Alves, José Albino da Paz, et al.

Neurology 2019;92;e1801-e1802

DOI 10.1212/WNL.0000000000007270

This information is current as of April 8, 2019

\section{Updated Information \& Services}

References

Subspecialty Collections

Permissions \& Licensing

Reprints including high resolution figures, can be found at: http://n.neurology.org/content/92/15/e1801.full

This article cites 3 articles, 1 of which you can access for free at: http://n.neurology.org/content/92/15/e1801.full\#ref-list-1

This article, along with others on similar topics, appears in the following collection(s):

MRI

http://n.neurology.org/cgi/collection/mri

Pediatric stroke; see Cerebrovascular Disease/ Childhood stroke http://n.neurology.org/cgi/collection/pediatric_stroke_see_cerebrovasc ular_disease-childhood_stroke

Information about reproducing this article in parts (figures,tables) or in its entirety can be found online at:

http://www.neurology.org/about/about_the_journal\#permissions

Information about ordering reprints can be found online: http://n.neurology.org/subscribers/advertise

Neurology ${ }^{\circledR}$ is the official journal of the American Academy of Neurology. Published continuously since 1951, it is now a weekly with 48 issues per year. Copyright @ 2019 American Academy of Neurology. All rights reserved. Print ISSN: 0028-3878. Online ISSN: 1526-632X.

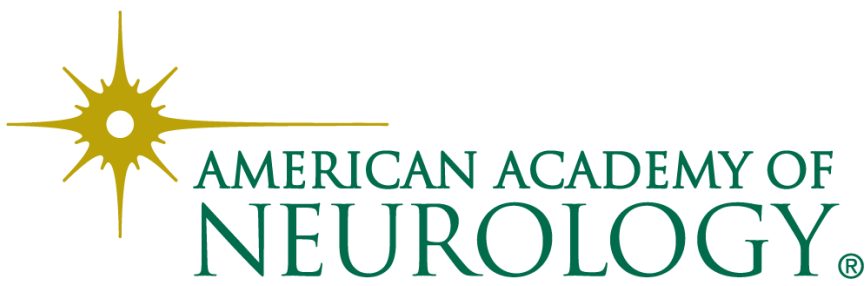

